\title{
The Effect of Long Term Irrigation by Treated Effluent on Boron Accumulation in
} Soil and Citrus Plants

\author{
Ra'fat Abu Daba'an' \\ Husam Al-Najar ${ }^{2} \nless$ \\ ${ }^{1,2}$ Civil and Environmental Engineering Department, Islamic University of Gaza. Gaza Strip, Palestine \\ Email:halnajar@iugaza.edu.ps.Tel+97082644400
}

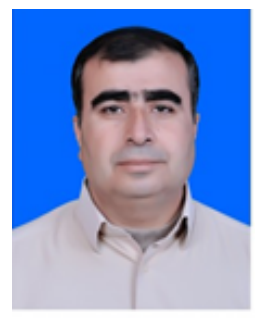

( Corresponding Author)

\begin{abstract}
The aim of the current research is to assess the long term effect of boron concentration in treated wastewater on citrus plants cultivated in various soil textures. Boron concentrations of treated wastewater used in sandy and clay soil were $1.45 \pm 0.37$ and $1.03 \pm 0.45 \mathrm{mg} / \mathrm{l}$, respectively. In sandy soil, Boron concentrations were $0.53 \pm 0.15$ and $3.94 \pm 0.97 \mathrm{mg} / \mathrm{kg}$ soil showed significant variation at $\mathrm{p}<0.05$ between the top $0-30$ and the second layer $30-60 \mathrm{~cm}$, respectively, while the leaves of citrus have boron concentration of $104.1 \mathrm{mg} / \mathrm{kg}$ dry weight. In clay soil boron concentrations were $0.79 \mathrm{mg} / \mathrm{kg}$ in both soil layers and in citrus leaves was $267.1 \mathrm{mg} / \mathrm{kg}$ dry weight which slightly exceeds the recommended limits $250 \mathrm{mg} / \mathrm{kg}$ dry weight. Therefore, the fate of Boron depends mainly on the soil texture; in the sandy soil leaching to deeper layers is occurred, while boron is accumulated in clay soil and citrus leaves. Thus, the municipal treated wastewater could be used safely to irrigate citrus cultivated in sandy soil textures.
\end{abstract}

Keywords: Boron, Citrus, Desalination, Gaza strip, Treated effluent.

Citation | Ra'fat Abu Daba'an; Husam Al-Najar (2018). The Effect of Long Term Irrigation by Treated Effluent on Boron Accumulation in Soil and Citrus Plants. Asian Review of Environmental and Earth Sciences, 5(1): 22-26.

History:

Received: 12 July 2018

Revised: 15 August 2018

Accepted: 21 September 2018

Published: 29 October 2018

Licensed: This work is licensed under a Creative Commons Attribution 3.0 License $($ (cc) $)$

Publisher:Asian Online Journal Publishing Group
Contribution/Acknowledgement: Both authors contributed to the conception and design of the study.

Funding: The authors would like to thank the Middle East Desalination Research Center (MEDRC) and Palestinian Water Authority (PWA) who kindly financialize the research project.

Competing Interests: The authors declare that they have no conflict of interests.

Transparency: The authors confirm that the manuscript is an honest, accurate, and transparent account of the study was reported; that no vital features of the study have been omitted; and that any discrepancies from the study as planned have been explained.

Ethical: This study follows all ethical practices during writing.

\section{Contents}

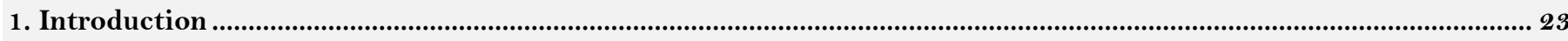

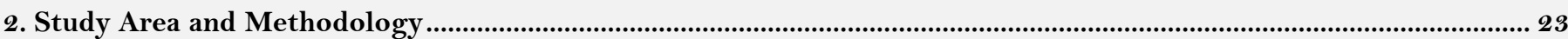

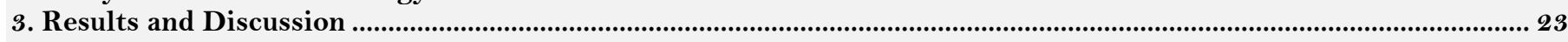

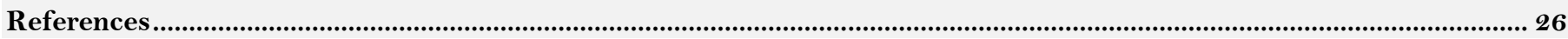




\section{Introduction}

Water consumption in the Gaza Strip is increasing continuously due to population increase resulting from natural growth, while the available water resources are decreasing due to urban development and increase of runoff which negatively affected the groundwater recharge [1-3]. The Gaza Strip is located in a semi-arid region categorized as sever water shortage area. The recharge of the groundwater from rainfall is insufficient to cover the demand, leading to imbalance in groundwater where seawater intrusion occurred deteriorating the groundwater quality [4]. Total up flow from groundwater beneath the Gaza Strip exceed $200 \mathrm{Mm}^{3}$ per year [5]. Virtually two third of groundwater pumped by 10000 wells used for agriculture propose, causing around $110 \mathrm{Mm}^{3}$ annual deficit of water balance. Therefore, it is important to preserve potable groundwater for domestic use and to reuse the treated effluent for irrigation constituting an additional renewable and trustworthy water resource [6, 7].

The maximum quantity of treated effluent expected to reach $92 \mathrm{MCM}$ per year by 2020 [8] may be used for irrigation of all irrigated areas cultivated with citrus, olives and other fruit trees. Gaza groundwater wells contain high concentrations of boron and this was clear after performing boron tests on some wells covering different regions. The tests showed that many water wells contains boron with concentration $>1.2 \mathrm{mg} / \mathrm{l}$, while wastewater contains boron concentration up to $4 \mathrm{mg} / \mathrm{l}[9]$.

Not all crops are equally sensitive to boron; some plants can show boron deficiency at a concentration that would be toxic to a different plant. Boron at levels greater than $0.3-0.5 \mathrm{mg} / \mathrm{l}$ in irrigation water found to be toxic for citrus plants [10-12]. Due to the proposed strategic plan of the Palestinian Water Authority (PWA), which mainly depends on the seawater desalinated for domestic supply, the first desalination stage can remove boron to $1.8 \mathrm{mg} / \mathrm{l}$ to suite the WHO regulation for drinking purposes. Boron concentration will increase massively in the wastewater and will lead to a boron problem specially it would harm the corps which will be irrigated by the treated wastewater. Therefore, the levels of boron toxicity in citrus as a most sensitive plant among the common plants in the Gaza Strip will be investigated based on Boron concentration and soil texture to answer the question whether more stages are required for boron removal to reuse the treated effluent for irrigation.

\section{Study Area and Methodology}

In 2004, the Job Creation Program (JCP) in cooperation with Palestinian Hydrologists Group has proposed a project to use treated effluent from Sheikh Ejleen wastewater treatment plant for irrigating of 100 dunums (1 dunum $=1000 \mathrm{~m}^{2}$ ) of citrus planted in clay soil. The project has been established under French fund and the supervision of Palestinian Water Authority (PWA) and Municipality of Gaza with coordination with Ministry of Health $(\mathrm{MOH})$ and Ministry of Agriculture In parallel, with a fund of the Catalan Government, the JCP in close cooperation with PWA and Coastal Municipal Water Utility (CMWU), launched a small pilot project 60 dunums for reuse of treated effluent. The irrigation system is a drip irrigation system in sandy soil planted with citrus.

\subsection{Sampling of Treated Effluent, Soil and Citrus leaves}

48 soil samples from each site were collected from the fields at two different depths $(0-30 \mathrm{~cm})$ and $(30-60 \mathrm{~cm})$. Samples were collected from leaves of citrus from 20 different trees in each site in addition to 10 samples were collected from irrigation water from each pilot project, nitric acid $\left(\mathrm{HNO}_{3}\right)$ was added to samples stored in polyethylene containers to meet quality standard precautions

\subsection{Soil Extraction}

The following steps describes the Boron extraction method by hot water according to university of Georgia modified procedure from Bercer and Truog [13]; Gupta [14].

1. Weigh of $10 \mathrm{~g}$ air-dried, 2 -mm sieved soil into $100 \mathrm{ml}$ plastic flasks.

2. $50 \mathrm{ml}$ deionized water added to the soil sample.

3. The flasks incubated in hot water shaking bath for 30 minutes at $80^{\circ} \mathrm{C}$.

4. To remove the extract from the soil, the samples are filtered by $150-\mathrm{mm}$ diameter filter paper into $100 \mathrm{ml}$ plastic flasks.

5. The filtration process is repeated to obtain clear supernatant for Boron extract measurement.

\subsection{Boron determination}

Boron in the treated effluent, soil and plant leaves extracts were determined using atomic emission spectroscopy by inductively coupled plasma (ICP-AES). The instrument was manufactured by SPECTRO GENESIS company that has a detection limit of $1.25 \mu \mathrm{g} / \mathrm{l}$.

\section{Results and Discussion}

\subsection{Boron Concentration of Treated Effluent}

As previously described in the study area, samples from two location were collected from the irrigation water, soil and plant tissue. As shown in Figure 1, the treated effluent has Boron concentration of $1.03 \pm 0.45$ and $1.45 \pm$ $0.37 \mathrm{mg} / 1$ from the clay and sandy soil sites, respectively. The high Boron concentration in the treated effluent at both sites refers to the Boron concentration in the groundwater which accounted for 1.13 and $1.03 \mathrm{mg} / \mathrm{l}$ at clay and sandy soil locations, respectively. Referring to Vengosh, et al. [15] study prepared to investigate the source of boron in the Southern Mediterranean Coastal Aquifer including Gaza coastal aquifer (Figure 2), Boron concentration in the groundwater is higher than $1 \mathrm{mg} / 1$ which is the limitation of WHO for drinking water. Moreover, the study proved that the main source of boron is the rocks of the aquifer [9, 15]. It is worth to mention that the treated effluent has higher Boron concentration than the groundwater due to the added Boron from detergents and domestic uses. 


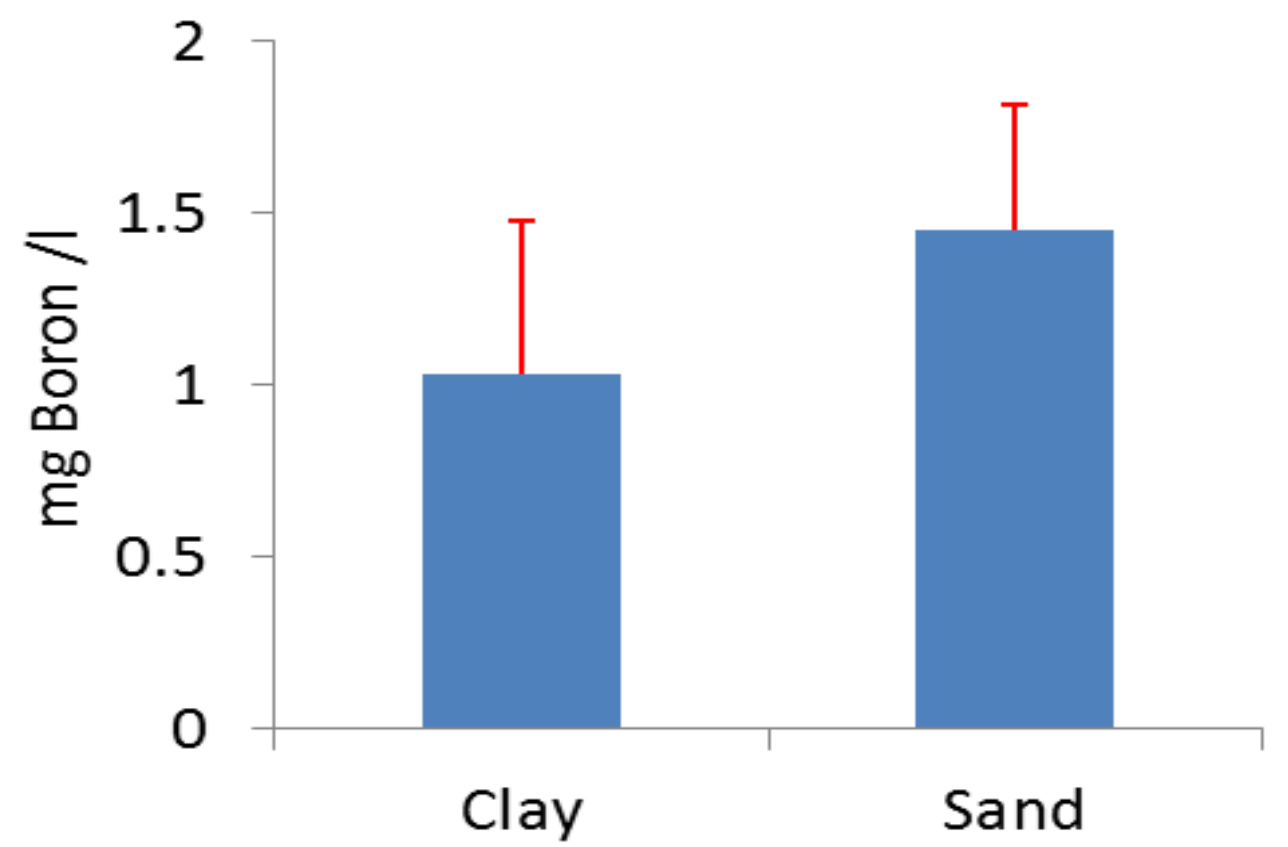

Figure-1. Boron concentration in the treated effluent that used in irrigation in clay and sandy soils

Boron concentration in irrigation water is classified to three categories in terms of its effect to the plants, none, moderate and sever. Israel, Saudi Arabia, Japan and states like California and Florida have quite strict guidelines of extreme boron concentrations ranging from 0.4 to $1 \mathrm{mg} / 1$ for irrigation purposes [16]. In Canada a guideline for irrigation water ranging from $0.5-6 \mathrm{mg} / \mathrm{l}$ according to crop sensitivity for Boron [17] whereas groundwater and the treated effluent mostly higher than $1 \mathrm{mg} / \mathrm{l}$ in the Gaza Strip.

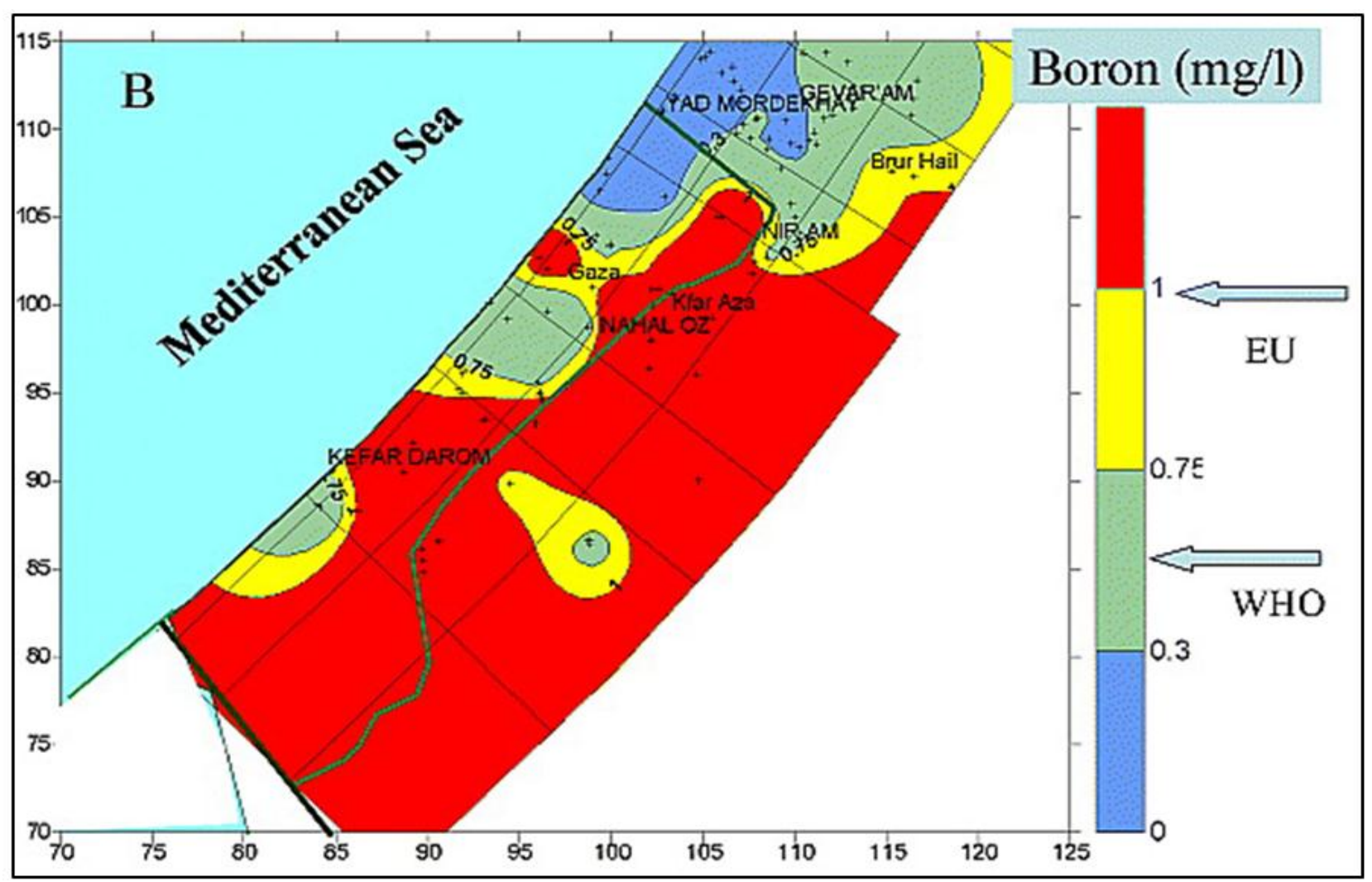

Figure-2. Distribution of boron concentrations in the Gaza Strip wells, EU and WHO restricted limits [15]

\subsection{Boron Accumulation in the Soil}

As shown in Figure 3, samples from various depths $0-30$ and $30-60 \mathrm{~cm}$ were collected from clay soil site showed insignificant differences in both soil layers at $p<0.05$. Boron concentrations accounted for $0.79 \pm 0.24$ and $0.78 \pm 0.30 \mathrm{mg} / \mathrm{kg}$ soil, respectively. In sandy soil, the results showed significant variation at $\mathrm{p}<0.05$ between the top $0-30 \mathrm{~cm}$ layer and the second layer $30-60 \mathrm{~cm}$. Boron concentration accounted for $0.53 \pm 0.15$ and $3.94 \pm 0.97$ $\mathrm{mg} / \mathrm{kg}$ soil, respectively. The sandy soil leached Boron to the lower layers, while this was not seen in clay soil site. Boron from irrigation water like most of the minerals can accumulate in the soils but it has higher affinity than other minerals. In soils, boron may be found in four forms: organically bound, soluble in soil water, adsorbed in soil surface, and fixed at clay minerals. Arid, saline soils generally contain the highest boron concentration. In sandy soils, boron is leached more readily than in clay soils and is thus less likely to accumulate to toxic concentrations. The Canadian Environmental Quality (CCME) Guidelines suggest guideline of $2 \mathrm{mg} / \mathrm{kg}$ soil boron [17]. This soil guideline is based on the protection of plants as the most sensitive receptor to boron, which is consistent with irrigation water being among the most restrictive of the water quality guidelines. 


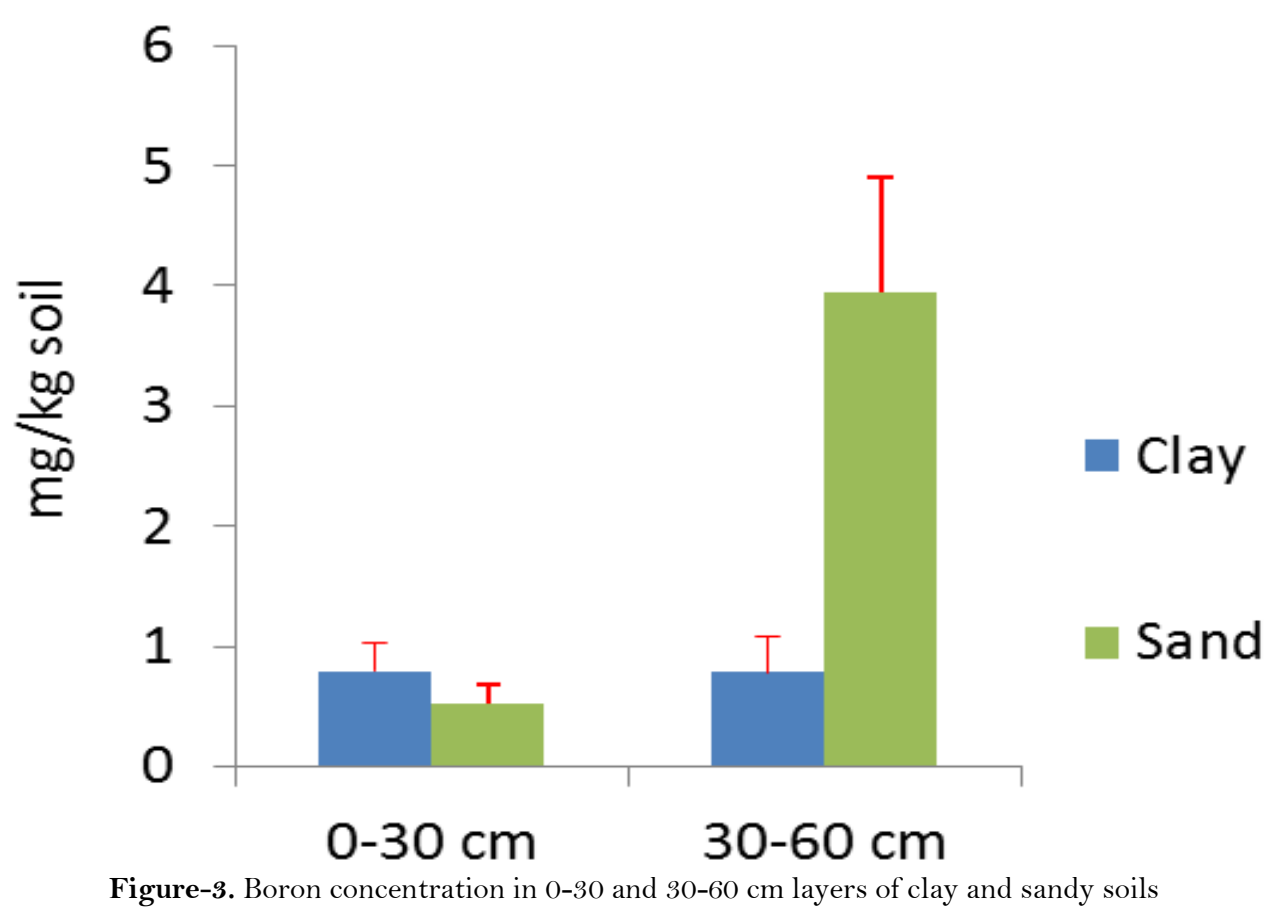

\subsection{Boron in the Leaves of Citrus}

Boron concentration in the leaves of citrus planted in clay soil accounted for $267.08 \pm 15.35 \mathrm{mg} / \mathrm{kg}$ dry matter. Significant lower concentration at $\mathrm{p}<0.05$ is detected from citrus leaves planted in sandy soil and accounted for $104.10 \pm 9.54 \mathrm{mg} / \mathrm{kg}$ dry matter (Figure 4). The difference in the concentration refers to the different soil texture, the sandy soil leaching of Boron to deep soil layers is tested in comparison to clay soil. In general Boron concentration in plants irrigated by treated effluent has high concentration, but it is far down toxicity threshold in most cases. However, there is a danger for reaching toxicity threshold in the case of long term irrigation for citrus in clay soil because of high accumulation of boron in leaves of citrus cultivated in clay soil reach to $267 \mathrm{mg} \mathrm{B} / \mathrm{kg}$ DM that exceeded the toxicity threshold 250-260 $\mathrm{mg} \mathrm{B} / \mathrm{kg} \mathrm{DM}[18]$.

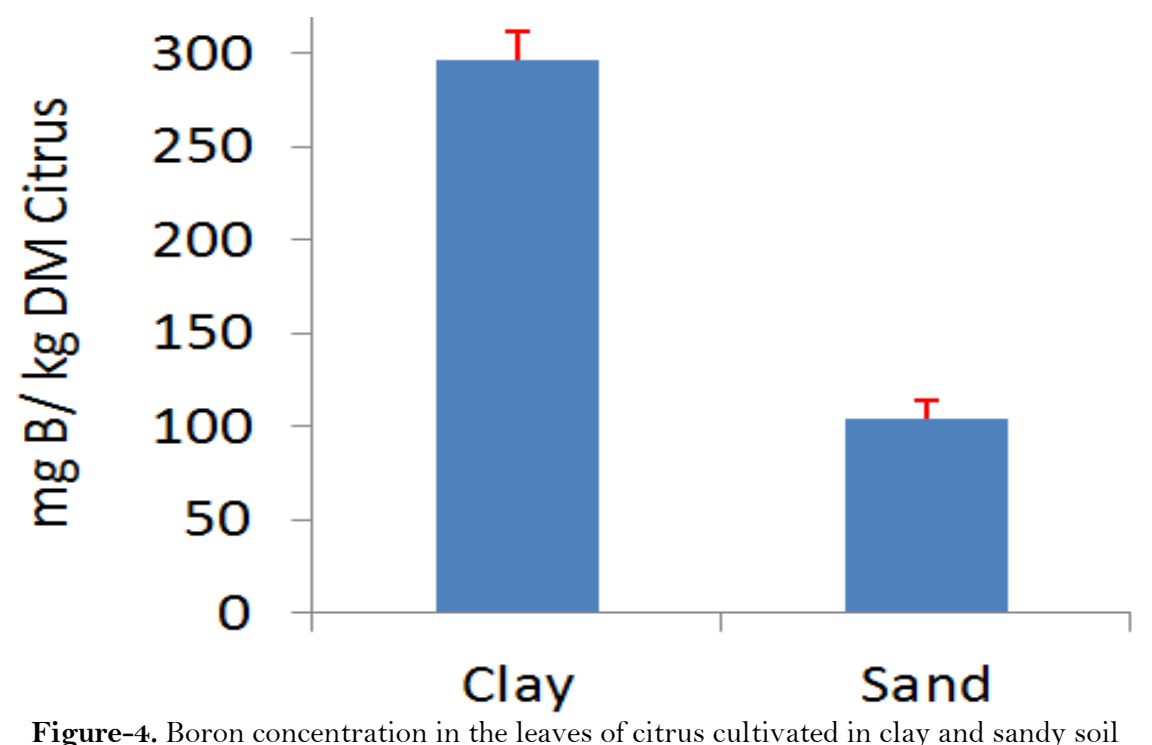

The high Boron concentration in the leaves of citrus at clay soil site in comparison with the leaves Boron concentration at sandy soil site is due to the variation of the soil $\mathrm{pH}$ at both sites and the leaching of Boron from the sandy soil (Figure 3). The soil pH is 8.18 and 7.8 in clay and sandy soil, respectively. Boron bioavailability is reduced at moderately high $\mathrm{pH}$ values of 7.5-8.5 [19]. The probability of boron uptake due to high $\mathrm{pH}$ may be partially offset by the excess of boron present in treated effluent.

Both soil layers at clay soil site has EC ranges from 1.49 and $1.77 \mathrm{ds} / \mathrm{m}$. While at sandy soil site the top layer EC equals 4.51 , while the lower layer has $10.56 \mathrm{ds} / \mathrm{m}$. Leaching of salts is emphasized in the sandy soil by the increased soil salinity at lower layers, while this was not clear at clay soil.

Use of treated effluent has significant prospective as a continued source of supplementary irrigation water, growing affectedly in water deficit regions like the Middle East and north Africa. Due to its climate similarity, Citrus is the most commonly cultivated crop which is suitable to be irrigated with treated effluent because of the acceptable distance between the fruit and irrigation water networks. This minimize the contamination with microorganisms. More concern should be given to the effluent quality form inorganic standpoint such as Boron sensitive crop.

Citrus in southern Florida was irrigated with $0.31 \mathrm{mg} \mathrm{B} / 1$ treated effluent for more than 10 years [20]. Leading to annual increase of $4.6 \mathrm{mg} \mathrm{B} / \mathrm{kg}$ dry weigh in leaves, but leaf concentrations still less than the toxic levels. Nevertheless, if the same irrigation water with $0.31 \mathrm{mg} \mathrm{B} / 1$ still in use for 30 years, leaf B concentrations will reach the harmful level $(200 \mathrm{mg} \mathrm{B} / \mathrm{kg})$. The main constrains of long term use of treated effluent are salinity and Boron concentration in most of the reuse studies. For instance in Murcia, Spain, treated effluent with 1.4 and $221 \mathrm{mg} / 1$ Boron and chloride concentrations are limiting values for long term reuse in case of lemon irrigation [18, 21]. The installation of reverse osmosis plant in Eilat produces potable water with Boron concentration suite the 
domestic use, but farmers who used the treated effluent for irrigation observed discolored leaves of citrus due to the relatively high Boron concentration levels for irrigation purposes [22].

In conclusion Soil texture has abundant evidence in retain boron in the soil. Boron concentration of both soil layer at clay site is $0.78 \mathrm{mg} / \mathrm{kg}$ soil when irrigated by treated effluent of $1.13 \mathrm{mg} / \mathrm{l}$. While the top layer $0-30 \mathrm{~cm}$ at sandy site is much lower Boron concentration than the deeper layer $30-60 \mathrm{~cm}$ and accounted for 0.5 and $3.9 \mathrm{mg} / \mathrm{kg}$ soil when irrigated by treated effluent of $1.03 \mathrm{mg} \mathrm{B} / \mathrm{l}$, respectively. The sandy soil leached boron to the lower layers, thus unlikely to accumulate to toxic concentrations in citrus. The concentration of boron in citrus planted in sandy soil is less than the planted in clay soil and accounted for 104 and $267 \mathrm{mg} / \mathrm{kg}$ dry weight, respectively.

\section{References}

[1] S. M. Hamdan, U. Troeger, and A. Nassar, "Stormwater availability in the Gaza strip, Palestine," International Journal of Environment and Health, vol. 1, pp. 580-594, 2007.Available at: https://doi.org/10.1504/ijenvh.2007.018582.

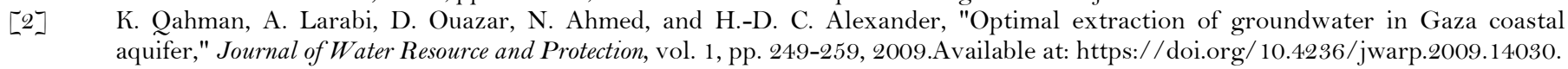
H. Al-Najar, "The integration of FAO-cropwat model and GIS techniques for estimating irrigation water requirement and its application in the Gaza strip," Natural Resources, vol. 2, pp. 146-154, 2011 1.Available at: https://doi.org/10.4236/nr.201 1.23020.

[4] M. Jarboo and H. Al-Najar, "Climate change and its impact on domestic water consumption in Sub-urban regions in the Gaza strip," International Journal of Climate Change Strategies and Management, vol. 7, pp. 3-16, 2015.Available at: https://doi.org/10.1108/ijccsm-07-2013-0092.

[5] Palestinian Water Authority PWA, Evaluation of water resources in the five governorates of Gaza strip: Water Resources Planning Directorate, 2015. PWA library. Gaza, Gaza Strip: Water Resources Planning Directorate, 2015.

[6] H. Al-Najar, Urban agriculture and eco-sanitation: The strategic potential toward poverty alleviation in the Gaza strip. London: RICS Research, 2007.

[7] Coastal Municipalities Water Utility CMWU, Annual Report on Water Status in the Gaza Strip. Summary about Water and Wastewater Situation in Gaza Strip. Gaza, Palestinian2016.

[8] Palestinian Water Authority PWA, Water resources and management. Gaza, Palestinian: Water Resources and Planning Department, 2014 .

[9] A. S. Ouda, "Investigate the boron content reduction from seawater reverse osmosis permeate by ion exchange method (Case study: SWRO Desalination Plant of Gaza Power Station)," Master Thesis. Civil Engineering Department. Islamic UniversityGaza. Gaza, Palestine, 2014

[10] WHO (World Health Organization), Safe abortion: Technical and policy guidance for health systems, 2nd ed. Geneva: Geneva, 2003.

[11] M. M. Shaaban, "Role of boron in plant nutrition and human health," American Journal of Plant Physiology, vol. 5, pp. 224-240, 2010.Available at: https://doi.org/10.3923/ajpp.2010.224.240.

[12] C. M. Grieve, S. R. Grattan, and E. V. Maas, "Plant salt tolerance," Agricultural Salinity Assessment and Management, vol. 2, pp. 405$459,2012$.

[13] K. Bercer and E. Truog, "Boron determination in soils and plants using the quinalizarin reaction," Industrial and Engineering Chemistry. Analytical Edition, vol. 11, pp. 540-545, 1939.

[14] U. C. Gupta, "A simplified method for determining hot-watersoluble boron in podzol soils," Soil Science, vol. 103, pp. 424-428, 1967.Available at: https://doi.org/10.1097/00010694-196706000-00009.

[15] A. Vengosh, W. Kloppmann, A. Marei, Y. Livshitz, A. Gutierrez, M. Banna, C. Guerrot, I. Pankratov, and H. Raanan, "Sources of salinity and boron in the Gaza strip: Natural contaminant flow in the Southern Mediterranean coastal aquifer," Water Resources Research, vol. 41, pp. Wo1013-1, 2005.Available at: https://doi.org/10.1029/2004wro03344.

[16] P.-K. Park, S. Lee, J.-S. Cho, and J.-H. Kim, "Full-scale simulation of seawater reverse osmosis desalination processes for boron removal: Effect of membrane fouling," Water Research, vol. 46, pp. 3796-3804, 2012.Available at: https://doi.org/10.1016/j.watres.2012.04.021.

[17] Alberta Environment and Sustainable Resource Development (AESRD), Alberta tier 1 soil and groundwater remediation guidelines. Alberta, Canada: Land and Forestry Policy Branch, Policy Division, 2014a.

[18] S. Grattan, F. Diaz, F. Pedrero, and G. Vivaldi, "Assessing the suitability of saline wastewaters for irrigation of Citrus spp: Emphasis on boron and specific-ion interactions," Agricultural Water Management, vol. 157, pp. 48-58, 2015.Available at: https://doi.org/10.1016/j.agwat.2015.01.002.

[19] R. O. Nable, G. S. Bañuelos, and J. G. Paull, "Boron toxicity," Plant and Soil, vol. 193, pp. 181-198, 1997.Available at: https://doi.org/10.1007/978-94-0 11-5580-9_12.

[20] B. Pereira, Z. He, P. Stoffella, and A. Melfi, "Reclaimed wastewater: Effects on citrus nutrition," Agricultural Water Management, vol. 98, pp. 1828-1833, 2011 .Available at: https://doi.org/10.1016/j.agwat.2011.06.009.

[21] F. Pedrero and J. J. Alarcón, "Effects of treated wastewater irrigation on lemon trees," Desalination, vol. 246, pp. 631-639, 2009.Available at: https://doi.org/10.1016/j.desal.2008.07.017.

[22] C. Fritzmann, J. Löwenberg, T. Wintgens, and T. Melin, "State-of-the-art of reverse osmosis desalination," Desalination, vol. 216 , pp. 1-76, 2007.Available at: https://doi.org/10.1016/j.desal.2006.12.009. 